\title{
Knowledge, Awareness, and Attitude Regarding Dental Implants among Dental Interns
}

\author{
Arati Sharma, ${ }^{1}$ Bidhan Shrestha, ${ }^{2}$ Bijay Kumar Chaudhari,, ${ }^{3}$ Pramita Suwal, ${ }^{1}$ Raj Kumar Singh \\ 'Department of Prosthodontics, CODS, B.P. Koirala Institute of Health Sciences, Dharan, Nepal, ${ }^{2}$ Department of \\ Prosthodontics, Kantipur Dental College and Hospital, Kathmandu, Nepal, ${ }^{3}$ Department of ENT, NAMS, Bir Hospital, \\ Kathmandu, Nepal.
}

\section{ABSTRACT}

Introduction: Implant therapy is an elective dental procedure of dental rehabilitative treatment. Objective of this study was to assess the knowledge, awareness, and attitude of dental interns of Nepal toward dental implants and to see associations of the responses with gender and geographic location of dental college.

Methods: It was conducted from June 2016 to June 2017 after taking ethical clearance and approval from the research committee. The sample included the interns who were present at the time of the survey. Data collection was done through a cross-sectional questionnaire survey, during clinical postings of the interns at all the dental colleges of Nepal, supervised and monitored by the investigators themselves; coded and entered in Microsoft Excel 2013 and statistical analysis was done by SPSS 20 version.

Results: A majority of the interns said they are moderately well informed about dental implants 141 (50.36\%); main advantage of dental implants is they are conservative 164 (58.6\%); most important factor for implant success is case selection 143 (51.07\%); the longevity of dental implants is 10-20yrs, $162(57.85 \%), 188(67.14 \%)$ agreed that they were not provided with sufficient information and 191 $(68.21 \%)$ stated that they need more information; 180 (64.3\%) felt the difficulty encountered while placing implants is average and $229(81.78 \%)$ stated that they need more hygiene care than natural teeth. There were major differences in the mindset to some other questions. Significant associations were seen with the location of college for some responses.

Conclusions: A majority of interns have knowledge regarding dental implants, but the percentage of those who gave unsatisfactory answers is also large. They have a positive attitude towards gaining more information through various means.

\section{Keywords: dental education; dental implant(s); implant dentistry; oral and maxillofacial surgery; oral} rehabilitation; prosthetic dentistry.

\section{INTRODUCTION}

Implant therapy is considered as the optimal option for rehabilitation of missing teeth. Loss of dentition in the elderly and middle-aged is still prevalent in modern society. ${ }^{1}$ The goal of modern dentistry is to maintain normal function, speech, aesthetic and health of the patient which are achieved by oral implants having a

Correspondence: Dr. Arati Sharma, Department of Prosthodontics, CODS, B.P. Koirala Institute of Health Sciences, Dharan, Nepal. Email: aratisharma122@yahoo.com, Phone: +977. 9819014415 . 
high success rate and good predictability when used for rehabilitation. ${ }^{2,3}$ Implant therapy is an elective dental procedure. ${ }^{4}$ Dental interns, who are easily available to the patients must inform them regarding this therapeutic option. Interns must have some knowledge about dental implants to deal with patients.

There are numerous articles regarding awareness about dental implants among the general public but few articles were found to assess the awareness in the dental profession. ${ }^{5-8}$ Many surveys have shown that the primary source of patient information on dental implants are dentists. ${ }^{9,10}$

Awareness about dental implants is increasing among general public and greater number of people are seeking information about it. So, the objective of this study was to assess the knowledge, awareness, and attitude of dental interns of Nepal towards dental implants.

\section{METHODS}

A cross-sectional questionnaire based descriptive study was conducted from June 2016 to June 2017 after taking ethical clearance and approval from the research committee of B.P. Koirala Institute of Health Sciences. The study population was all the interns of Nepal and the sample included all those who were present at the time of survey (consecutive sampling). Sample size was estimated by informing about the proposed study and enquiring the administrative body of each dental college about the number of interns. Data were collected through a cross-sectional questionnaire survey. Consent was taken from the dental colleges and each participant. A pre-used questionnaire was taken from an article, a pilot study was carried out and minor modification was made in the questionnaire. ${ }^{11}$ Data collection was done during the clinical postings of the interns and an effort was made to include a maximum number of interns. It was supervised and monitored by the investigators themselves. The collected data were coded and entered in Microsoft Excel 2013 and statistical analysis was done by SPSS 20 version. Chi-Square test was applied to see the associations.

\section{RESULTS}

Total number of interns was calculated to be around 350. Three hundred fifty questionnaires were distributed of which 280 responses were received. The response rate was high $280(80 \%)$. All the questionnaires were completely filled. Of the total number of respondents, $90(32 \%)$ were males and $190(68 \%)$ were females.

A majority of interns said they are moderately well informed about dental implants 141 (50.36\%), felt the difficulty encountered while placing implants is average
$180(64.3 \%)$ and main advantage of dental implants is they are more conservative 164 (58.6\%). Significant association was seen with geographic location of college for the first question (Table 1).

A majority of them said the most important factor for implant success is case selection 143 (51.07\%), 162 $(57.85 \%)$ said the longevity of dental implants is 10 20 years, and implants need more hygiene care than natural teeth $229(81.78 \%)$. Significant associations were seen with geographic location of college for those responses. The responses 'implant type and material' and 'experience of operator' were significantly associated with colleges out of Kathmandu. Similarly, the responses '10-20 years' and 'yes, need more care than natural teeth' were also significantly associated with colleges out of Kathmandu (Table 2).

To the questions about the cost of procuring a dental implant from an implant company and initial set-up cost required to incorporate implant surgery into practice, there were major differences in the mindset of the interns. A majority of them said economic feasibility will limit the usages of implants in Nepal 142 (50.71\%). No significant association was seen with gender and location of college (Table 3).

A majority of them agreed that they were not provided with sufficient information about implant treatment procedures during their BDS program 188 (67.14\%) and would like more to be provided in the curriculum 191 (68.21\%) (Table 4).

There were major differences in the mindset regarding preferred sources of more information and training on implants. Significant associations were seen with the location of dental college. The responses 'Short-term CDE programs and workshops conducted by the implant companies' and 'professional newsletters and books' for additional reliable information were significantly associated with colleges located in Kathmandu and nearby places. Whereas, the responses 'Dental consultants and specialists' and 'study groups and the internet' were significantly associated with colleges out of Kathmandu (Table 5).

Regarding training on implants the highest percentage of respondents said one-year certificate or modulebased courses conducted by colleges or trained implantologists 136 (48.57\%). The response 'fellowship programs conducted by universities' was significantly associated with colleges in Kathmandu and nearby places. Whereas, the response 'MSc programs (full time $=1$ year, part time $=2$ years $)^{\prime}$ was significantly associated with colleges out of Kathmandu (Table 5). 


\begin{tabular}{|c|c|c|c|c|c|c|c|c|}
\hline \multirow{2}{*}{\multicolumn{2}{|c|}{ Questions }} & \multirow[b]{2}{*}{ n (\%) } & \multicolumn{3}{|c|}{ Gender } & \multicolumn{3}{|c|}{ Location of college } \\
\hline & & & $\begin{array}{l}\text { Male } \\
\text { n (\%) }\end{array}$ & $\begin{array}{c}\text { Female } \\
\text { n (\%) }\end{array}$ & P-value & $\begin{array}{l}\mathrm{KTM}^{*} \\
\mathrm{n}(\%)\end{array}$ & $\begin{array}{c}\text { Out of } \\
\text { KTM } \\
n(\%)\end{array}$ & $P$ value \\
\hline \multicolumn{9}{|c|}{$\begin{array}{l}\text { How well informed are you } \\
\text { about dental implants? }\end{array}$} \\
\hline 1. & Very well & $35(12.5)$ & $13(14.4)$ & $22(11.6)$ & & $23(17.8)$ & $12(7.9)$ & \\
\hline 2. & Well & $90(32.14)$ & $28(31.1)$ & $62(32.6)$ & & $48(37.2)$ & $42(27.8)$ & \\
\hline 3. & Moderately well & $141(50.36)$ & $41(45.5)$ & $\begin{array}{l}100 \\
(52.6)\end{array}$ & & $51(39.5)$ & $90(59.6)$ & \\
\hline 4. & Poorly & $14(5)$ & $8(8.9)$ & $6(3.2)$ & 0.167 & $7(5.4)$ & $7(4.6)$ & 0.005 \\
\hline 5. & Not at all & - & - & - & & - & - & \\
\hline \multicolumn{9}{|c|}{$\begin{array}{l}\text { On a scale of } 1-10, \text { how } \\
\text { difficult do you feel is it to place } \\
\text { implants as compared to other } \\
\text { dental procedures? }\end{array}$} \\
\hline 1. & $1=$ very easy & $59(21.1)$ & $15(16.7)$ & $44(23.2)$ & & $27(20.9)$ & $32(21.2)$ & \\
\hline 2. & $5=$ average & $180(64.3)$ & $56(62.2)$ & $\begin{array}{l}124 \\
(65.2)\end{array}$ & & $80(62.0)$ & $100(66.2)$ & \\
\hline 3. & $10=$ very difficult & $41(14.6)$ & $19(21.1)$ & $22(11.6)$ & 0.078 & $22(17.0)$ & $19(12.6)$ & 0.564 \\
\hline \multicolumn{9}{|c|}{$\begin{array}{l}\text { What do you think is the main } \\
\text { advantage of dental implants } \\
\text { as compared to other tooth- } \\
\text { replacement modalities? }\end{array}$} \\
\hline 1. & Aesthetics; looks nicer & $9(3.2)$ & $4(4.4)$ & $5(2.6)$ & & $7(5.4)$ & $2(1.3)$ & \\
\hline $\begin{array}{l}2 . \\
\text { Do } \\
\text { toc }\end{array}$ & $\begin{array}{l}\text { More conservative; } \\
\text { tequire any adjacent } \\
\text { reparation }\end{array}$ & $164(58.6)$ & 57 (63.3) & $\begin{array}{l}107 \\
(56.3)\end{array}$ & & $73(56.6)$ & $91(60.3)$ & \\
\hline 3. & Longevity; lasts longer & $97(34.6)$ & $26(28.9)$ & $71(37.4)$ & & $44(34.1)$ & $53(35.1)$ & \\
\hline 4. & No additional advantage & $5(1.8)$ & $1(1.1)$ & $4(2.1)$ & 0.577 & $2(1.6)$ & $3(2.0)$ & 0.369 \\
\hline 5. & Do not know & $5(1.8)$ & $2(2.2)$ & $3(1.6)$ & & $3(2.3)$ & $2(1.3)$ & \\
\hline
\end{tabular}

"Kathmandu Valley and places nearby. 


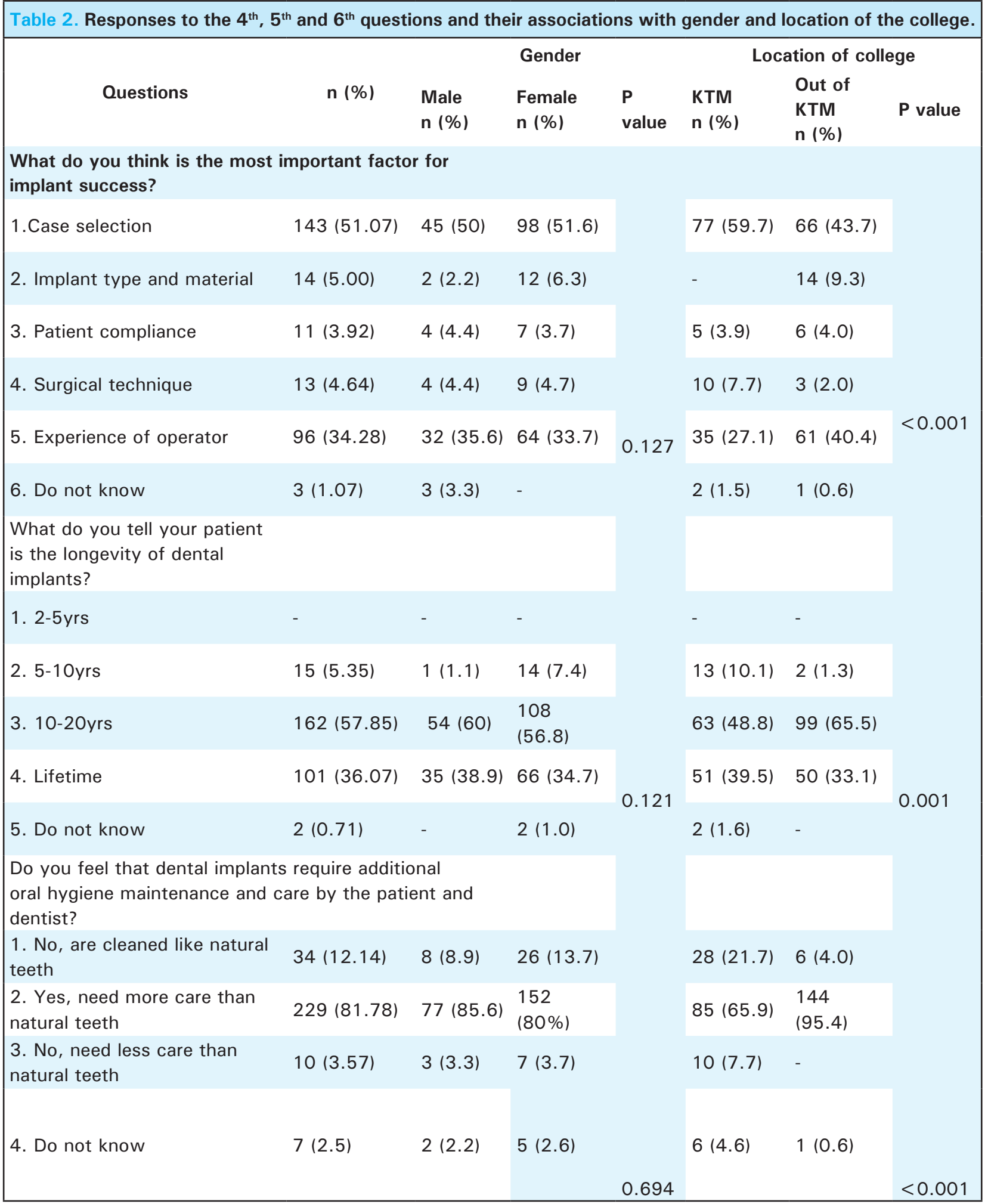


Table 3. Responses to the $7^{\text {th }}, 8^{\text {th }}$ and $9^{\text {th }}$ questions and their associations with gender and location of the college.

\begin{tabular}{|c|c|c|c|c|c|c|c|}
\hline \multirow[b]{2}{*}{ Questions } & \multirow[b]{2}{*}{ n (\%) } & \multicolumn{3}{|c|}{ Gender } & \multicolumn{3}{|c|}{ Location of college } \\
\hline & & n (\%)Male & $\begin{array}{l}\text { n (\%) } \\
\text { Female }\end{array}$ & $P$ value & KTM & $\begin{array}{l}\text { Out of } \\
\text { KTM }\end{array}$ & $P$ value \\
\hline \multicolumn{8}{|l|}{$\begin{array}{l}\text { What is the cost of procuring a } \\
\text { dental implant from an implant } \\
\text { company? }\end{array}$} \\
\hline 1. Rs.6-10 thousand & $85(30.35)$ & $25(27.8)$ & $\begin{array}{l}60 \\
(31.6)\end{array}$ & & $39(30.2)$ & $46(30.5)$ & \\
\hline 2. Rs. $10-15$ thousand & $96(34.28)$ & $35(38.9)$ & $\begin{array}{l}61 \\
(32.1)\end{array}$ & & 36 (27.9) & $60(39.7)$ & \\
\hline 3. Rs. $15-20$ thousand & $59(21.07)$ & $20(22.2)$ & $\begin{array}{l}39 \\
(20.5)\end{array}$ & & $30(23.2)$ & $29(19.2)$ & \\
\hline 4. Rs. $20-25$ thousand & $35(12.5)$ & $10(11.1)$ & $\begin{array}{l}25 \\
(13.2)\end{array}$ & 0.438 & $23(17.8)$ & $12(7.9)$ & 0.037 \\
\hline 5. Do not know & $5(1.78)$ & - & $5(2.6)$ & & $1(0.8)$ & $4(2.7)$ & \\
\hline \multicolumn{8}{|l|}{$\begin{array}{l}\text { How much do you feel is the } \\
\text { initial set-up cost required to } \\
\text { incorporate implant surgery into } \\
\text { practice? }\end{array}$} \\
\hline 1. Rs.2-3 Lacs & $90(32.14)$ & $30(33.3)$ & $\begin{array}{l}60 \\
(31.6)\end{array}$ & & $42(32.5)$ & $48(31.8)$ & \\
\hline 2. Rs.4-5 Lacs & $\begin{array}{l}114 \\
(40.71)\end{array}$ & $40(44.4)$ & $\begin{array}{l}74 \\
(38.9)\end{array}$ & & $51(39.5)$ & $63(41.7)$ & \\
\hline 3. Rs.5-10 Lacs & $54(19.28)$ & $14(15.6)$ & $\begin{array}{l}40 \\
(21.0)\end{array}$ & 0635 & $28(21.7)$ & $26(17.2)$ & 0647 \\
\hline 4. Rs. 10 Lacs and above & $22(7.85)$ & $6(6.7)$ & $16(8.4)$ & (1.00 & $8(6.2)$ & $14(9.3)$ & 0.07 \\
\hline \multicolumn{8}{|l|}{$\begin{array}{l}\text { Do you think that dental implants } \\
\text { are an acceptable solution for } \\
\text { missing teeth in the Nepalese } \\
\text { scenario? }\end{array}$} \\
\hline 1. Yes, implants are here to stay & $\begin{array}{l}115 \\
(41.07)\end{array}$ & $36(40)$ & $\begin{array}{l}79 \\
(41.6)\end{array}$ & & $48(37.2)$ & $67(44.4)$ & \\
\hline $\begin{array}{l}\text { 2. No, economic feasibility will } \\
\text { limit their usage }\end{array}$ & $\begin{array}{l}142 \\
(50.71)\end{array}$ & $48(53.4)$ & $\begin{array}{l}94 \\
(49.5)\end{array}$ & & $64(49.6)$ & $78(51.7)$ & \\
\hline $\begin{array}{l}\text { 3. No, too invasive for patient } \\
\text { acceptance }\end{array}$ & $20(7.14)$ & $5(5.5)$ & $15(7.9)$ & & $15(11.6)$ & $5(3.3)$ & \\
\hline $\begin{array}{l}\text { 4. No, other reasons: (please } \\
\text { specify) }\end{array}$ & $3(1.07)$ & $1(1.1)$ & $2(1.0)$ & 0.876 & $2(1.5)$ & $1(0.6)$ & 0.043 \\
\hline
\end{tabular}


Table 4. Responses to the $10^{\text {th }}$ and $11^{\text {th }}$ Questions and their associations with gender and location of the college.

Gender Location of College

\begin{tabular}{|c|c|c|c|c|c|c|}
\hline Questions & n (\%) & $\begin{array}{l}\text { M } \\
n \\
(\%)\end{array}$ & $\begin{array}{l}\text { F } \\
n \\
(\%)\end{array}$ & $P$ value & $\begin{array}{l}\text { KTM } \\
\mathbf{n} \\
(\%)\end{array}$ & $\begin{array}{l}\text { Out of } \\
\text { KTM } \\
n \\
(\%)\end{array}$ \\
\hline
\end{tabular}

Were you provided sufficient information about implant treatment procedures during your BDS program?

\begin{tabular}{|c|c|c|c|c|c|}
\hline Yes & 92 (32.85) & $\begin{array}{l}35 \\
(38.9)\end{array}$ & $\begin{array}{l}57 \\
(30)\end{array}$ & $\begin{array}{l}47 \\
(36.4)\end{array}$ & $\begin{array}{l}45 \\
(29.8)\end{array}$ \\
\hline No & $188(67.14)$ & $\begin{array}{l}55 \\
(61.1)\end{array}$ & $\begin{array}{l}133 \\
(70)\end{array}$ & $\begin{array}{l}82 \\
(63.5)\end{array}$ & $\begin{array}{l}106 \\
(70.2)\end{array}$ \\
\hline
\end{tabular}

Would you like more information about implant treatment procedures to be provided in the BDS curriculum?

\begin{tabular}{|c|c|c|c|c|c|c|c|c|}
\hline 1. & Yes & $191(68.21)$ & $\begin{array}{l}61 \\
(67.8)\end{array}$ & $\begin{array}{l}130 \\
(68.4)\end{array}$ & 0.139 & $\begin{array}{l}80 \\
(62.0)\end{array}$ & $\begin{array}{l}111 \\
(73.5)\end{array}$ & 0.239 \\
\hline 2. & No & 89 (31.78) & $\begin{array}{l}29 \\
(32.2)\end{array}$ & $\begin{array}{l}60 \\
(31.6)\end{array}$ & 0.915 & $\begin{array}{l}49 \\
(38.0)\end{array}$ & $\begin{array}{l}40 \\
(26.5)\end{array}$ & 0.040 \\
\hline
\end{tabular}

Table 5. Responses to the $12^{\text {th }}$ and $13^{\text {th }}$ questions and their associations with gender and location of college.

Gender

$$
\text { Questions }
$$

$$
\text { n (\%) }
$$

$\mathrm{M}$
$\mathrm{n}$

(\%)

F

n
(\%)

From where would you like to get additional reliable information about dental implants?

1. Short-term CDE programs and workshops conducted by the implant companies.

$68(24.28) \quad 24(26.7) \quad 44$

(23.1)

2. One-year certificate or module-based courses conducted by colleges or trained implantologists.

3. Professional newsletters and books.

4. Dental consultants and specialists.

5. Study groups and the

\begin{tabular}{|c|c|c|c|}
\hline $93(33.21)$ & 32 (35.5) & $\begin{array}{l}61 \\
(32.1)\end{array}$ & \multirow{4}{*}{0.686} \\
\hline $56(20.0)$ & 15 (16.7) & $\begin{array}{l}41 \\
(21.6)\end{array}$ & \\
\hline $29(10.35)$ & $7(7.8)$ & $\begin{array}{l}22 \\
(11.6)\end{array}$ & \\
\hline $34(12.14)$ & $12(13.3)$ & $\begin{array}{l}22 \\
(11.6)\end{array}$ & \\
\hline
\end{tabular}
internet.

Out of

(\%) KTM n

$P$ value

(\%)

Location of College
Out of
KTM $\quad$ P value
$\mathbf{n}$
$(\%)$




\begin{tabular}{|c|c|c|c|c|c|c|c|}
\hline \multicolumn{8}{|l|}{$\begin{array}{l}\text { From where would you like } \\
\text { to receive training on dental } \\
\text { implants? }\end{array}$} \\
\hline $\begin{array}{l}\text { 1. Short-term CDE programs } \\
\text { and workshops conducted by } \\
\text { implant companies. }\end{array}$ & $36(12.85)$ & $13(14.4)$ & $\begin{array}{l}23 \\
(12.1)\end{array}$ & & $19(14.7)$ & $\begin{array}{l}17 \\
(11.2)\end{array}$ & \\
\hline $\begin{array}{l}\text { 2. One-year certificate } \\
\text { or module-based courses } \\
\text { conducted by colleges or } \\
\text { trained implantologists. }\end{array}$ & $\begin{array}{l}136 \\
(48.57)\end{array}$ & $43(47.8)$ & $\begin{array}{l}93 \\
(48.9)\end{array}$ & & $59(45.7)$ & $\begin{array}{l}77 \\
(51.0)\end{array}$ & \\
\hline $\begin{array}{l}\text { 3. Fellowship programs } \\
\text { conducted by universities. }\end{array}$ & 88 (31.42) & $28(31.1)$ & $\begin{array}{l}60 \\
(31.6)\end{array}$ & 0.956 & 51 (39.5) & $\begin{array}{l}37 \\
(24.5)\end{array}$ & $<0.001$ \\
\hline $\begin{array}{l}\text { 4. MSc programs (full } \\
\text { time }=1 \text { year, part } \\
\text { time }=2 \text { years) }\end{array}$ & $20(7.14)$ & $6(6.7)$ & $14(7.3)$ & & - & $\begin{array}{l}20 \\
(13.2)\end{array}$ & \\
\hline
\end{tabular}

\section{DISCUSSION}

A great majority of respondents in this survey were females. A majority of the respondents in our survey claimed to be moderately well informed $50.36 \%$ about dental implants and felt the difficulty encountered while placing implants is average $64.3 \%$. This is similar to the result obtained in a similar study done in India. ${ }^{11}$

A majority of interns said the main advantage of dental implants is they are more conservative $58.6 \%$ but $41.4 \%$ of the respondents gave other answers. In case of implant therapy, there is no need of reduction of adjacent teeth and thus, no question of abutment failure. ${ }^{11,12}$ Tooth supported fixed partial dentures have the long-term complications like secondary caries and abutment tooth failure. Whereas, the belief that implants yield a better long-term prognosis than tooth has now clearly been rejected in several comparative studies and systematic reviews. Teeth even compromised because of periodontal disease or endodontic problems may have a longevity that surpasses by far that of the average implant. ${ }^{13}$

A majority of the respondents said the most important factor for implant success is case selection $51.07 \%$. Clearly, patient selection is of paramount importance when dental implants are being considered and the criteria are based on age, local factors of the patient, systemic factors of the patient, educational level and economic considerations, patient's willingness and compliance to undergo surgery etc. which are obtained during history taking and examination of the patient. ${ }^{14-17}$ Though there is no absolute contraindication for implant surgery, there is a relative percentage of failure and success. In a developing country like Nepal, where patients are often unaware of any underlying medical problems, it may be necessary to carry out a baseline full blood count, blood glucose along with bone profile to rule out common but easily corrected diseases like anemia, diabetes mellitus and bone diseases before starting implant treatment.

Surgical trauma and/or limited surgical experience has also been considered by many to be one of the most important causative factors in early implant failure. Early failure rates of implants are twice among surgeons who have placed fewer than 50 implants than those who have placed more than 50 implants. ${ }^{18}$ In this study also $34.28 \%$ of the respondents said that experience of the operator is the most important factor for implant success. This is different from the result of a similar study where only $12.2 \%$ of the interns said 'experience of operator'. ${ }^{11}$

In our study, a majority of the respondents $57.85 \%$ said that the longevity of dental implants is $10-20$ years, whereas $36.07 \%$ said the longevity is lifetime. Such perception that implants last lifetime could lead to highly unrealistic patient expectations. There is poor evidence of studies long enough ( $\geq 20 y r$ follow-up) on survival rates of implants to help us answer this question. One study found that the survival rates of dental implants according to the bone density were: type I-97.6\%, type II-96.2\%, type III-96.5\%, and type IV $-88.8 \% .{ }^{19}$ Another study found a 10-year cumulative survival rate of $97.9 \%$ of ITI dental implants placed in the posterior jaw. ${ }^{20}$ A 20-year life table analysis of a longitudinal study of more than 12,500 Ankylos Dental implants found that the Kaplan-Meier cumulative survival rate was 93.3\% after 204 months and concluded that Ankylos dental implants followed for up to 20 years have high cumulative survival rates. ${ }^{21}$

Most of the respondents $81.78 \%$ felt that dental implants require additional oral hygiene maintenance and care than natural teeth, which is very true. Once implants have been placed in the edentulous region routine 
maintenance, recall evaluations and radiographs are necessary to ensure the long life of these restorations. Hygiene with dental implants is so tedious and critical to their long-term success that the patient and dental professional must exercise considerable effort. ${ }^{22,23}$

In this study, no definitive consensus was reached regarding the cost of procuring a dental implant from an implant company and that required to incorporate implant surgery into practice, which shows their poor clinical exposure and more of textbook based knowledge.

A total of $50.71 \%$ of the respondents said that they think dental implants are not an acceptable solution for missing teeth in Nepalese scenario because economic feasibility will limit their usages, whereas $41.07 \%$ said yes, implants are here to stay. The responses are similar to the survey conducted in India. ${ }^{11}$ The studies conducted in Austria, The United States and Japan have shown the patient's concern regarding the high cost of dental implants. ${ }^{11}$ Although implant therapy may look to be more expensive than other treatment modalities for the first time, during the lifetime of the patient retreatment of the crowns and root-canals actually endup costing more to the patient. Interns should be aware of this fact so that they can educate the patients who feel this treatment modality is costly than others.

A majority of the students $67.14 \%$ agreed that they were not provided sufficient information about implant treatment procedures during their BDS program and would like more information to be provided in the BDS curriculum $68.21 \%$. When asked from where would they like to get additional reliable information about dental implants and training on dental implants, 33.21\% and $48.57 \%$ respectively said, 'one-year certificate or module-based courses conducted by colleges or trained implantologists'. A majority was not gained by any response which indicated major differences in the mindset of the respondents. In a study conducted to know the preferred source and perceived need of more information about dental implants by the undergraduate students of Nepal, ${ }^{24}$ highest percentage of those below 5 th year preferred dental consultants and specialists as reliable source of more information, whereas the highest percentage of $5^{\text {th }}$ year preferred one-year certificate or module-based courses conducted by colleges or trained implantologists as a reliable source.

Significant associations of the responses to some questions were seen with the location of the dental college. The reason may be accessibility to the sources of information due to a geographic location of the college. Interns of the colleges located in Kathmandu and nearby places have better accessibility to the various sources of information than those posted in remote areas and out of Kathmandu.

A major increase in the number of implant treatments performed each year is occurring worldwide and it is increasingly being applied in general dental practice also in developed countries and it is clear that implant dentistry will occupy a significant part of the modern general dental practice in a developing country like Nepal also in the near future. So, there is a need to provide more information to the interns about dental implants so that they can at least guide the patients in the selection of proper treatment modality.

\section{CONCLUSIONS}

A majority of interns have knowledge regarding dental implants, but the percentage of those who gave unsatisfactory answers is also large. There is a need of providing adequate information about dental implants to the interns. They have perceived the need of more information and have a positive attitude towards getting it through various sources. There is also a need of considering the barriers to access the various sources of information due to the geographic location of the colleges.

\section{ACKNOWLEDGEMIENT}

We want to thank all the participants and our colleagues at various Dental colleges of Nepal who have supported directly and indirectly in the conduction of this survey.

\section{Conflict of Interest: None.}

\section{REFERENCES}

1. Narby B, Kronström M, Söderfeldt B, P.S. Prosthodontics and the patient: what is oral rehabilitation need? Conceptual analysis of need and demand for prosthodontic treatment. Part 1: a conceptual analysis. Int J Prosthodont. 2005;18(1):75-9. [PubMed]

2. Oshida Y, Tuna E B, Aktoren O, Gencay K. Dental implant systems. Int J Mol Sci. 2010;11(4):1580-678. [PubMed]
3. Masters DH, Tatum H Jr. Dental implants. J Am Dent Assoc. 1995;126(9):1210. [PubMed]

4. Zitzmann NU, Sendi P, Marinello CP. An economic evaluation of implant treatment in edentulous patients: Preliminary results. Int J Prosthodont. 2005;18(1):20-7. [PubMed] 
5. Müller F, Salem K, Barbezat C, Herrmann F R, Schimmel M. Knowledge and attitude of elderly persons towards dental implants. Gerodontology. 2012;29(2):914-23. [PubMed]

6. Faramarzi M, Shirmohammadi A, Chisazi MT, Kashefimehr A, Farhoodi E, Omrani A. Patient's Knowledge Regarding Dental Implants in Tabriz, Iran. Avicenna Journal of Dental Research. 2013;4(1):43-8. [Full Text]

7. Ariani N, Mursid S, Odang RW, Sukotjo C, Kusdhany LS. Indonesian undergraduate dental students' perceptions toward implant treatment and education. J Investig Clin Dent. 2013;4(2):107-12. [PubMed | PMC]

8. Zimmer CM, Zimmer WM, Williams J, Liesener J. Public awareness and acceptance of dental implants. Int J oral Maxillofac implants. 1992;7(2):228-32. [PubMed]

9. Pommer B, Zechner W, Watzak G, Ulm C, Watzek G, Tepper G. Progress and trends in patients' mindset on dental implants. I: Level of information, sources of information and need for patient information. Clin Oral Implants Res. 2011;22(2):223-9. [PubMed]

10. Chowdhary R, Mankani N. \& Chandraker NK. Awareness of dental implants as a treatment choice in urban Indian populations. Int $\mathrm{J}$ Oral Maxillofac Implants. 2010;25(2):305-8. [PubMed]

11. Chaudhary S, Gowda TM, Kumar TA, Mehta DS. Knowledge and attitudes of dental interns in Karnataka State, India, regarding implants. J Dent Educ. 2013;77(10):1365-70. [PubMed | PMC]

12. Jivraj $\mathrm{S}$ and Chee W. Rationale for dental implants. Br Dent J. 2006;200(12):661-5. [PubMed]

13. Elemam Ranya Faraj and Pretty Iain. Comparison of the Success Rate of Endodontic Treatment and Implant Treatment. ISRN Dent. 2011;2011:1-8. [PubMed]

14. Hatim NA, Al-Rawee RY and Tawfeeq BA. Criteria for selection of Implant cases. Al-Rafidain Dent J. 2006;6(2):161-70. [Full Text]

15. Abullais SS, AlQahtani NA, Kudyar N and Priyanka N. Success of dental implants: Must-know prognostic factors. J Dent Implant. 2016;6:44-8. [Full Text]
16. Davda LS and Davda SV. Implant dentistry: A multidisciplinary approach. J Interdiscip Dentistry. 2013;3(2):52-6. [Full Text]

17. Herrmann I, Lekholm U, Holm S and Kultje C. Evaluation of patient and implant characteristics as potential prognostic factors for oral implant failures. Int J oral Maxillofac Implants. 2005;20(2):220-30. [PubMed]

18. Porter Judith A and Fraunhofer JA. Success or failure of dental implants? A literature review with treatment considerations. Gen Dent. 2005;53(6):423-32. [PubMed]

19. Goiato MC and Pellizzer EP. Longevity of dental implants in type IV bone: a systematic review. Int J Oral Maxillofac Surg. 2014;43(9):1108-16. [PubMed]

20. Blanes RJ, Bernard JP, Blanes ZM, and Belser UC. A 10-year prospective study of ITI dental implants placed in the posterior region. I: Clinical and radiographic results. Clin Oral Implants Res. 2007;18(6):699-706. [PubMed]

21. Krebs Mischa, Schmenger Kai, Neumann K. Long-Term Evaluation of Ankylos Dental Implants, Part I: 20-Year Life Table Analysis of a Longitudinal Study of More Than 12,500 Implants. Clin Implant Dent Relat Res. 2015;17(1):275-86. [PubMed]

22. Jepsen S, Berglundh T, Genco R, Aass AM, Demirel K, Figuero E et al. Primary prevention of periimplantitis: managing peri-implant mucositis. J Clin Periodontol. 2015;16:152-7. [ubMed | PMC]

23. Gulati M, Govila V, Anand V, and Anand B. Implant Maintenance: A Clinical Update. Int Sch Res Notices. 2014:908534. [릴ed]

24. Sharma A et al. Preferred Source and Perceived Need of More Information about Dental Implants by the Undergraduate Dental Students of Nepal: All Nepal Survey. Int J Dent. 2018:6794682. [PubMed] 